\title{
Avaliação da Qualidade Microbiológica e Físico- Química de Águas de Minas do Município de Rio Novo - MG
}

\author{
Tulio Zampa Lopes (I), Edilene Bolutari Baptista (I), Emília Maricato \\ Pedro dos Santos (I), Carolina dos Santos Fernandes da Silva (I) \\ (I) UNIPAC - Universidade Presidente Antônio Carlos (Av. Juiz de Fora, 1100 - Bairro Granjas \\ Bethânia - Juiz de Fora, MG.)
}

\section{Resumo}

A água é de fundamental importância para a manutenção da vida no planeta, e os benefícios proporcionados por ela são inúmeros. É utilizada para lazer, preparo de alimentos, higiene pessoal, matéria-prima na produção industrial e na fabricação de bens de consumo. No mundo, mais de 95\% da água disponível está na forma salgada, não sendo apropriada para o consumo humano e uma pequena porcentagem está na forma doce. O Brasil apresenta grande quantidade desse recurso, quando comparado a outros países, estando, neste quesito, em uma posição bastante privilegiada em relação ao restante do mundo. Porém, a distribuição da água dentro do território nacional não é uniforme, e grande parte da população não tem acesso à água tratada. O país apresenta uma grande extensão territorial, o que dificulta o monitoramento, levando a população a consumir água que muitas vezes não proporciona qualidade necessária para o consumo. Água potável é aquela que reúne características que a coloca na condição própria para o consumo do ser humano, portanto deve estar livre de qualquer tipo de contaminação que possa prejudicar a saúde humana. O presente trabalho teve como objetivo avaliar a qualidade microbiológica e físico-química de diferentes fontes de água naturais que são utilizadas para consumo pela população do município de Rio Novo-MG. Foram coletadas águas de pontos diferentes da cidade (minas) e realizadas análises microbiológicas e físico-químicas. Na análise microbiológica realizou-se pesquisa de

\footnotetext{
Referência:

Tulio Zampa Lopes, Edilene Bolutari Baptista, Emília Maricato Pedro dos Santos, Carolina dos Santos Fernandes da Silva. Avaliação da Qualidade Microbiológica e Físico-Química de Águas de Minas do Município de Rio Novo - Mg. In: Anais do $12^{\circ}$ Congresso Latinoamericano de Microbiologia e Higiene de Alimentos - MICROAL 2014 [= Blucher Food Science Proceedings, num.1, vol.1]. São Paulo: Editora Blucher, 2014. DOI 10.5151/foodsci-microal-201
} 
coliformes $30^{\circ} \mathrm{C}$, Escherichia coli e contagem de bactérias heterotróficas. Em relação às análises físico-químicas, foram realizadas determinação do $\mathrm{pH}$, acidez, alcalinidade, condutividade, determinação de cloretos e nitratos, dureza e turbidez. No que diz respeito às análises físico-químicas, todas as amostras apresentaram resultados satisfatórios. Entretanto, considerando os parâmetros microbiológicos analisados, somente um terço das amostras está apropriado para o consumo humano. Sessenta e seis por cento das amostras estavam inapropriadas para o consumo por apresentar pelo menos um tipo de contaminação microbiológica: $50 \%$ das amostras inadequadas apresentaram contaminação por coliformes a $30^{\circ} \mathrm{C}$ e $50 \%$ apresentaram contaminação por coliformes a $30^{\circ} \mathrm{C}$ e E. coli. Os resultados demostraram que do total de minas analisadas, $33 \%$ encontraram-se de acordo com as normativas estabelecidas pela Portaria 2914/2011 do Ministério da Saúde.

Palavras-Chave: água potável, análise físico-química, análise microbiológica, coliformes, Escherichia coli

Agência de Fomento: 